\title{
Utilization of Ammonium Chloride as a Novel Selective Depressant in Reverse Flotation of Potassium Chloride
}

\author{
Runqing Liu ${ }^{1,2} \mathbb{D}$, Hongyu Lu ${ }^{1,2}$, Li Wang ${ }^{1,2, *}$, Mengjie Tian ${ }^{1,2}$ and Wei Sun ${ }^{1,2, *}$ \\ 1 School of Minerals Processing and Bioengineering, Central South University, Changsha 410083, China; \\ liurunqing@126.com (R.L.); luhongyuxu@163.com (H.L.); 15200826490@163.com (M.T.) \\ 2 Key Laboratory of Hunan Province for Clean and Efficient Utilization of Strategic Calcium-containing \\ Mineral Resources, Central South University, Changsha 410083, China \\ * Correspondence: li_wang@csu.edu.cn (L.W.); sunmenghu@csu.edu.cn (W.S.); \\ Tel.: +86-731-88830482 (L.W. \& W.S.); Fax: +86-0731-88660477 (L.W. \& W.S.)
}

Received: 14 November 2018; Accepted: 10 January 2019; Published: 13 January 2019

\begin{abstract}
The separation of sylvite $(\mathrm{KCl})$ and halite $(\mathrm{NaCl})$, two main minerals in potash ores, is difficult because of the high ion concentration, fine particles of $\mathrm{NaCl}$, and aggregation of $\mathrm{KCl}$ and $\mathrm{NaCl}$ in the saturated system. This study employed ammonium chloride $\left(\mathrm{NH}_{4} \mathrm{Cl}\right)$ as a new depressant and dodecyl morpholine as a collector in the reverse flotation process. The depressing mechanisms were studied by adsorption capacity experiments, infrared spectral analysis, and molecular dynamics simulations. The flotation tests showed that $\mathrm{NaCl}$ recovery increased to $97 \%$ after the addition of $\mathrm{NH}_{4} \mathrm{Cl}$, while $\mathrm{KCl}$ recovery was reduced to $<1 \%$. Notably, $\mathrm{NH}_{4} \mathrm{Cl}$ not only acted as a selective $\mathrm{KCl}$ depressant, but also activated $\mathrm{NaCl}$ flotation. The FTIR measurements showed that $\mathrm{NH}_{4} \mathrm{Cl}$ was physically adsorbed onto the $\mathrm{KCl}$ and $\mathrm{NaCl}$ surfaces. Adsorption capacity experiments and molecular dynamics simulations confirmed more favorable $\mathrm{NH}_{4} \mathrm{Cl}$ adsorption on the $\mathrm{KCl}$ surface than on the $\mathrm{NaCl}$ surface. Moreover, the $\mathrm{KCl}$ mineral surface was more hydrophilic, while that of $\mathrm{NaCl}$ was more hydrophobic. Relative concentration analysis revealed that $>90 \%$ ammonium and chloride ions were distributed 2-10 ̊ away from the $\mathrm{KCl}$ surface but were dispersed on the $\mathrm{NaCl}$ surface, indicating that $\mathrm{NH}_{4} \mathrm{Cl}$ exhibited stronger intermolecular interactions with $\mathrm{KCl}$ than with $\mathrm{NaCl}$.
\end{abstract}

Keywords: $\mathrm{KCl} ; \mathrm{NaCl} ; \mathrm{NH}_{4} \mathrm{Cl}$; flotation; molecular dynamics simulations

\section{Introduction}

Potash is a significant raw material in medicine, food, and other chemical industries and is most notably used as a fertilizer in agriculture [1,2]. Among all the mineral salt species used in sylvite $(\mathrm{KCl})$ production, halite $(\mathrm{NaCl})$ separation is very difficult because of its high ion concentration, fine particles, and its aggregation with $\mathrm{KCl}$ in a saturated system. Thus, globally, most potash ores are concentrated by froth flotation [3]. In this process, direct flotation collectors comprise alkyl fatty amines [4] and alkyl sulfonates [5], while reverse flotation collectors contain carboxylic acids [6], amides [7], and morpholines [8].

Previous studies $[9,10]$ have shown that in the flotation of $\mathrm{KCl}$, aliphatic primary amines with C12-C18 carbon chain lengths exhibit better flotation and the flotation effect improves as the carbon chain length increases. Currently, over $80 \%$ of the world's potash is produced by the selective flotation of $\mathrm{KCl}$ from $\mathrm{NaCl}$ and other gangue minerals using long-chain (C16-C22 aliphatic chains) amine collectors, as observed in potash mining in Saskatchewan [11]. However, the process of eliminating the $\mathrm{C} 16-\mathrm{C} 22$ long-chain amines is relatively harsh and comprises melting at temperatures in the range $70-90{ }^{\circ} \mathrm{C}$ and neutralization with hydrochloric or acetic acids [12]. In the actual flotation process, 
the amine collector of the $\mathrm{KCl}$ concentrate products afforded smaller granularity, captured $\mathrm{NaCl}$ fine particles to concentrate the products, and degraded the quality of the concentrate, thereby hindering the production of highly pure $\mathrm{KCl}$. Alkylmorpholine has been employed as a reverse flotation collector of $\mathrm{KCl}$. Alkylmorpholine sorption at the halite surface proceeds with high selectivity, creating the conditions necessary for efficient and selective flotation separation of $\mathrm{NaCl}$ and $\mathrm{KCl}$ [8]. This process does not require the addition of auxiliary agents and shows relatively good flotation index [13]. Currently, the reverse flotation method is being applied in the potash industry, including operations in the Dead Sea (Israel and Jordan), Verkhnekamskoye (Russia), and Chaerhan Salt Lake (Qinghai province, China). Dodecyl morpholine (DMP) was used as a collector to float $\mathrm{NaCl}$ from carnallite in the Qinghai Salt Lake Group operations, whereby $\sim 50 \mathrm{~g} / \mathrm{t}$ carnallite feed was employed. The flotation recovery of $\mathrm{NaCl}$ was $\sim 90 \%$, while the $\mathrm{KCl}$ grade in the final product was in the range $90-95 \%$, with an overall $\mathrm{KCl}$ recovery of 59-62\% [13]. However, dodecyl morpholine continues to carry $\mathrm{KCl}$ during flotation. Thus, for industries with high-quality $\mathrm{KCl}$ requirements, obtaining high-quality $\mathrm{KCl}$ products remains a problem.

Alkyl amines, which are used as direct flotation collectors, are selectively adsorbed onto $\mathrm{KCl}[14,15]$. Thus, it follows that $\mathrm{NH}_{4} \mathrm{Cl}$ can also be effectively adsorbed onto the $\mathrm{KCl}$ surface because its ammonium ion is similar to the alkyl ammonium ion. However, the alkyl amine hydrophobic carbon chains increase the hydrophobicity of the mineral surface. Hence, the $\mathrm{KCl}$ surface is more hydrophilic after the addition of $\mathrm{NH}_{4} \mathrm{Cl}$ because this depressant does not comprise a hydrophobic carbon chain and its chloride ion is hydrophilic. Thus, $\mathrm{NH}_{4} \mathrm{Cl}$ is the ideal $\mathrm{KCl}$ depressor in theory. In this study, the effect of $\mathrm{NH}_{4} \mathrm{Cl}$ as a depressor in the DMP flotation of $\mathrm{KCl}$ was elucidated. Furthermore, the mechanism of $\mathrm{NH}_{4} \mathrm{Cl}$ adsorption was investigated through adsorption experiments, infrared spectroscopy, and molecular dynamics (MD) simulations.

\section{Experimental}

\subsection{Materials and Reagents}

Analytically pure $\mathrm{KCl}$ and $\mathrm{NaCl}$ samples were used as pure minerals. Both samples were dry ground and sieved. The fractions of pure $\mathrm{KCl}$ and $\mathrm{NaCl}$ with the particle sizes 165-200 $\mu \mathrm{m}$ and $<200 \mu \mathrm{m}$, respectively, were obtained as flotation samples and used as single minerals. The X-ray powder diffraction spectra revealed that the purities of the $\mathrm{KCl}$ and $\mathrm{NaCl}$ samples were $98 \%$ and $99 \%$, respectively. Both minerals were ground in a ceramic ball mill and the fractions in the size range 38-74 $\mu \mathrm{m}$ were used in the flotation tests. Deionized water with a resistivity $>18 \mathrm{M} \Omega \cdot \mathrm{cm}$ was used in all the experiments. The reagents used in the study are listed in Table 1.

Table 1. Reagents used in experiments.

\begin{tabular}{|c|c|c|c|}
\hline Chemical & Concentration & Supplier & Role \\
\hline $\mathrm{KCl}$ & $98 \%$ & $\begin{array}{l}\text { Sinopharm Chemical Reagent } \\
\text { Co., Ltd., Beijing, China }\end{array}$ & Pure minerals \\
\hline $\mathrm{NaCl}$ & $99 \%$ & $\begin{array}{l}\text { Sinopharm Chemical Reagent } \\
\text { Co., Ltd., Beijing, China }\end{array}$ & Pure minerals \\
\hline $\mathrm{MgCl}_{2} \cdot 6 \mathrm{H}_{2} \mathrm{O}$ & $99 \%$ & $\begin{array}{l}\text { Sinopharm Chemical Reagent } \\
\text { Co., Ltd., Beijing, China }\end{array}$ & $\begin{array}{l}\text { Preparation of } \\
\text { saturated brine }\end{array}$ \\
\hline $\mathrm{CaSO}_{4} \cdot 2 \mathrm{H}_{2} \mathrm{O}$ & $99 \%$ & $\begin{array}{l}\text { Sinopharm Chemical Reagent } \\
\text { Co., Ltd., Beijing, China }\end{array}$ & $\begin{array}{l}\text { Preparation of } \\
\text { saturated brine }\end{array}$ \\
\hline $\mathrm{NH} 4 \mathrm{Cl}$ & $99 \%$ & $\begin{array}{l}\text { Sinopharm Chemical Reagent } \\
\text { Co., Ltd., Beijing, China }\end{array}$ & Regulator \\
\hline DMP & - & In-house & Collector \\
\hline
\end{tabular}

The saturated brines were prepared by dissolving a sufficient amount of salt (Table 2) in Millipore water with stirring for $2 \mathrm{~h}$. The saturated solutions were then stored at room temperature for $24 \mathrm{~h}$ and filtered before use. The DMP solution $(0.01 \mathrm{~g} / \mathrm{L}, 99 \%$ purity) was prepared in the laboratory with 
saturated brine as the solvent. Flotation tests were conducted using DMP as the collector and $\mathrm{NH}_{4} \mathrm{Cl}$ as the regulator. All the reagents used in the tests were of analytical grade.

Table 2. Ingredients of salt brine.

\begin{tabular}{cccccc}
\hline Composition & $\mathbf{M g C l}_{\mathbf{2}}$ & $\mathbf{N a C l}$ & $\mathbf{K C l}$ & $\mathrm{CaSO}_{4}$ & $\mathbf{H}_{\mathbf{2}} \mathbf{O}$ \\
\hline Content (\%) & 33.60 & 0.55 & 0.37 & 0.14 & 65.34 \\
\hline
\end{tabular}

\subsection{Flotation Tests}

The single-mineral flotation $\mathrm{KCl}$ and $\mathrm{NaCl}$ tests were conducted on an XFG flotation machine (Exploring Machinery Plant, Changchun, China) with a volume of $50 \mathrm{~mL}$ and an impeller speed of $1850 \mathrm{rpm}$ (Figure 1). A well-configured and filtered saturated brine solution was used as the flotation medium. In each test, $10 \mathrm{~g}$ mineral sample and $40 \mathrm{~mL}$ saturated brine solution were added in the cell and conditioned for $3 \mathrm{~min}$. The flotation experiment was divided into two parts: first, the suspension was dosed with 900-1500 g/t DMP as the collector. Subsequently, to test the effect of $\mathrm{NH}_{4} \mathrm{Cl}$, the prepared $\mathrm{NH}_{4} \mathrm{Cl}$ was applied before adding the optimal DMP dosage. The depressant (if needed) and collector were added sequentially and conditioned for 5 and 10 min, respectively. After 10 min of flotation, the products were collected, dried, and weighed and the recovery was then calculated. The flotation flowsheet is displayed in Figure 2. Each flotation test was conducted in triplicate and the average was reported as the final value. The standard deviation, which is presented as an error bar, was obtained from the mean of the three measurements per experimental condition.

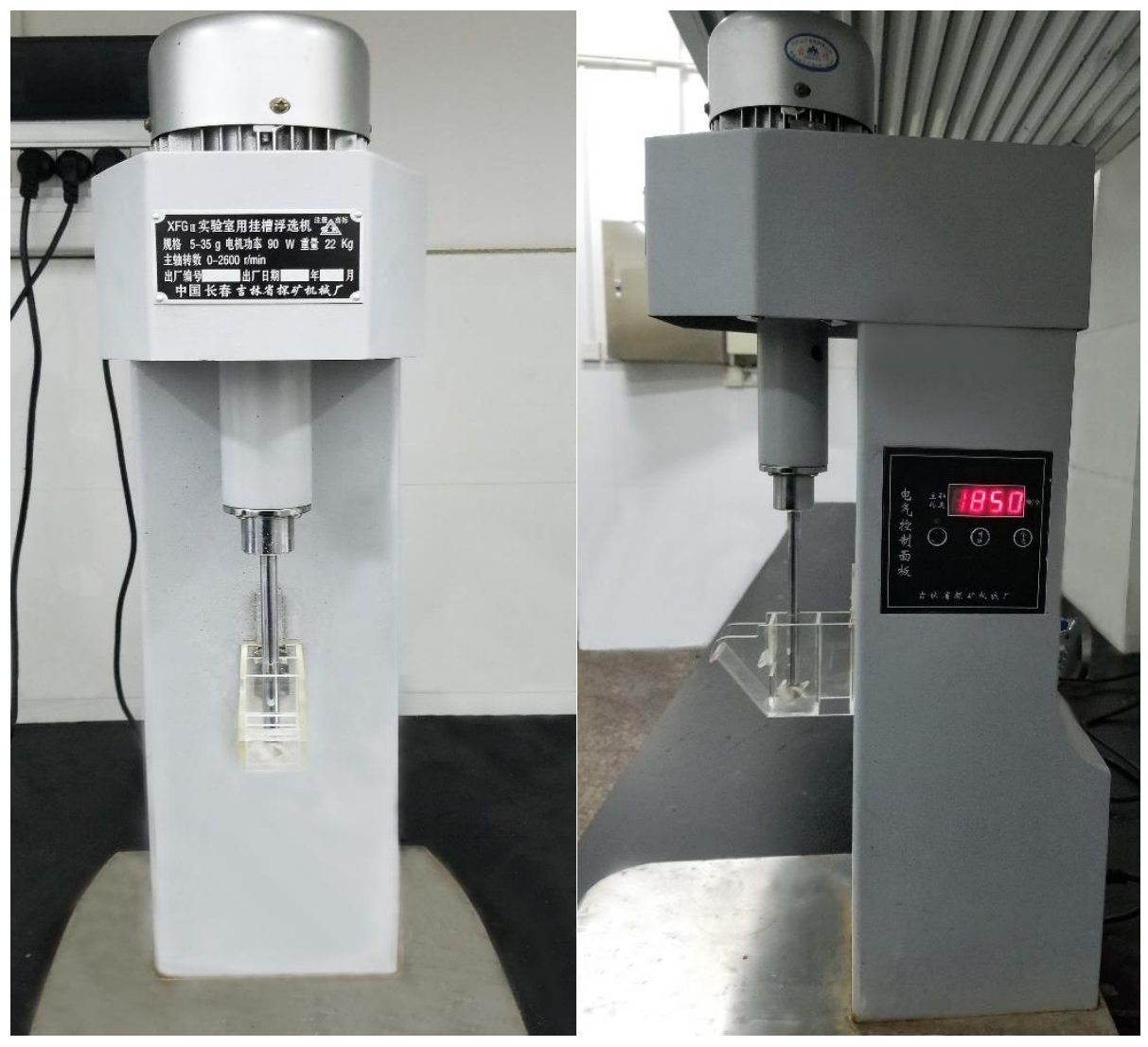

Figure 1. Schematic of the XFG series flotation machine. 


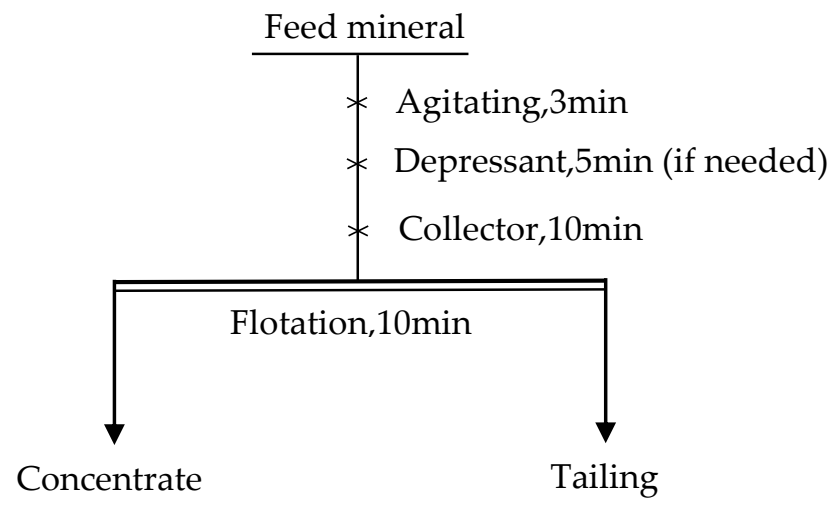

Figure 2. Flowsheet of the single-mineral flotation tests.

\subsection{Adsorption Measurements}

The adsorption measurements were completed using a total organic carbon analyzer (TOC-L $\mathrm{CPH} / \mathrm{CPN}$, Shimadzu Corporation, Kyoto, Japan). Different dosages were used as the dosing conditions, while a saturated salt brine solution with no added minerals was set as the reference group. A total of $10 \mathrm{~g}$ mineral was added to the experimental group, while no minerals were added to the reference group. The volume of the entire slurry was maintained at $40 \mathrm{~mL}$ after the addition of the mineral (in different dosages). All the pulp was placed in a clean beaker and stirred in a magnetic stirrer for $15 \mathrm{~min}$, after which the supernatant was withdrawn. The sample was diluted four-fold in a $50 \mathrm{~mL}$ PET tube and centrifuged for $15 \mathrm{~min}$ at a speed of 18,000 rpm to determine the total amount of organic carbon. The experiments were repeated at least in triplicate and the average data were plotted. The standard deviation, presented as an error bar, was obtained using the mean of the three measurements per experimental condition. The adsorption of the reagent on the mineral surface was calculated as follows $[16,17]$ :

$$
\Gamma=\frac{m_{1}-m_{2}}{m},
$$

where $\Gamma$ is the adsorption amount, $\mu \mathrm{g} / \mathrm{g}$ mineral; $m_{1}$ is the weight of total reagent in the solution measured in the reference group, $\mu \mathrm{g} ; m_{2}$ is the weight of total reagent in the solution measured in the experimental group, $\mu \mathrm{g}$; and $m$ is the weight of the mineral, $g$.

\subsection{Infrared Spectral Analysis}

Fourier-transform infrared spectroscopy (FTIR, Bio-Rad FTS-6000, Cambridge, MA, USA) was performed at room temperature in the range $4000-400 \mathrm{~cm}^{-1}$. After the pure minerals were conditioned with the reagents in the solution, the samples were filtered naturally, dried thoroughly in a vacuum oven at $40^{\circ} \mathrm{C}$, and ground to $<2 \mu \mathrm{m}$ in an agate mortar. The spectra of the solids were recorded using $\mathrm{KBr}$ pellets.

\subsection{Simulations}

The adsorption behavior of the ammonium ions on the $\mathrm{NaCl}(100)$ and $\mathrm{KCl}(001)$ surfaces was explored by MD simulation. The initial adsorption models were built using the software package, Materials Studio 6.0 (Dassault Systèmes BIOVIA, San Diego, CA, USA). The condensed-phase optimized molecular potentials for atomic simulation studies (COMPASS) force-field was used to calculate the inter- and intra-atomic interactions. Additionally, density functional theory calculations for the ammonium ion, $\mathrm{NaCl}(100)$ surface, and $\mathrm{KCl}(001)$ surface were implemented to assign the charges in the CASTEP module. The Perdew-Burke-Ernzerhof functional with a generalized gradient approximation was used throughout the study.

Based on the natural cleavage plane reported in previous studies $[18,19]$, the $\mathrm{NaCl}$ and $\mathrm{KCl}$ mineral surfaces were built to construct the adsorption models. After the mineral surface models were 
built, the amorphous cell, a packing module, was used for the construction of the reagent matrix on the surfaces. The chloride ions were added to maintain the system neutral. A strict reagent addition sequence (Figure 1) was adopted. The built vacuum slab (thickness ca. $80 \AA$ ) eliminated the influence of the period boundary conditions. During the simulation, the ammonium and chloride ions in the solution moved freely, while the $\mathrm{NaCl}$ and $\mathrm{KCl}$ sheets were fixed.

Molecular optimization was carried out using a Smart Minimizer to eliminate the possible overlap of molecules during the process of building the configuration. The simple point-charge model was used to simulate liquid water. The temperature was controlled by an Andersen thermostat. The canonical (NVT) ensemble was applied at the temperature $298 \mathrm{~K}$ for each system using a Nosé-Hoover thermostat, while the integration step was set at $1 \mathrm{fs}$. Finally, each system was simulated for 4 ns to reach the equilibrium state and the last 1 ns of each trajectory was used for the analysis.

\section{Results and Discussion}

\section{1. $\mathrm{NH}_{4} \mathrm{Cl}$ as a Depressant for $\mathrm{KCl}$ and $\mathrm{NaCl}$}

Figure 3a illustrates the effect of the DMP dosage on the flotation of $\mathrm{KCl}$ and $\mathrm{NaCl}$ in the absence of $\mathrm{NH}_{4} \mathrm{Cl}$. In this flotation system, the $\mathrm{NaCl}$ exhibited good flotability, while $\mathrm{KCl}$ presented a very poor flotation ability in the presence of the DMP collector. Further, with an increase in the collector dosage, in the range 900-1400 g/t, the flotation recovery increased monotonically and a maximum value of $93.13 \% \mathrm{NaCl}$ recovery was achieved at $1400 \mathrm{~g} / \mathrm{t}$ DMP. In the test dosage range 900-1500 g/t, the flotation recoveries of $\mathrm{NaCl}$ and $\mathrm{KCl}$ were $>70 \%$ and $<4.5 \%$, respectively. Comparatively, typical recoveries achieved in some of the flotation plants in Saskatchewan, which used long-chain amines as collectors, were in the range 85-88\% [11]. Qinghai Avic Resources Co., Ltd., in Mahai also employed traditional $\mathrm{KCl}$ flotation from $\mathrm{NaCl}$ with an amine as the collector to produce the final $\mathrm{KCl}$ product in the grade range $86-92 \%$ [13]. In this experiment, the loss of $\mathrm{KCl}$ was $>10 \%$ when long-chain amines were used as collectors, exceeding the maximum value $(4.5 \%)$ of $\mathrm{KCl}$ loss rate. This indicates that DMP exhibits a good selective collecting ability for $\mathrm{NaCl}$ and can be utilized to separate $\mathrm{NaCl}$ from $\mathrm{KCl}$.

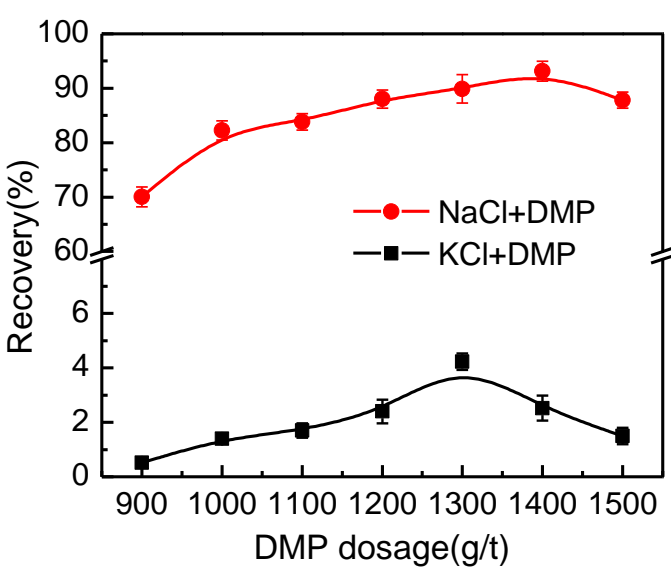

(a)

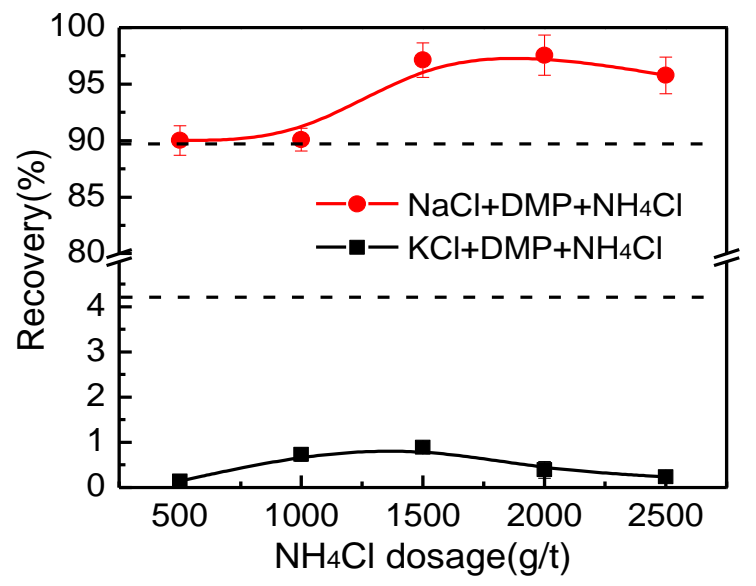

(b)

Figure 3. (a) Effect of the DMP dosage on the recovery of $\mathrm{KCl}$ and $\mathrm{NaCl}$ and (b) effect of $\mathrm{NH}_{4} \mathrm{Cl}$ dosage on the recovery of $\mathrm{KCl}$ and $\mathrm{NaCl}$ in the presence of DMP.

The flotation response was significantly different when $\mathrm{NH}_{4} \mathrm{Cl}$ was employed as the depressant. Figure $3 \mathrm{~b}$ illustrates the effect of $\mathrm{NH}_{4} \mathrm{Cl}$ dosage on the flotation of $\mathrm{KCl}$ and $\mathrm{NaCl}$ in the presence of DMP. The DMP dosage was fixed at $1300 \mathrm{~g} / \mathrm{t}$, the optimal dosage in the DMP flotation system. The $\mathrm{KCl}$ and $\mathrm{NaCl}$ recoveries were $4.23 \%$ and $89.88 \%$, respectively, in the absence of $\mathrm{NH}_{4} \mathrm{Cl}$. After the addition of $\mathrm{NH}_{4} \mathrm{Cl}$, the flotation of $\mathrm{KCl}$ was inhibited, while the recovery was $<1 \%$ in the test dosage range 500-2500 g/t. Interestingly, $\mathrm{NH}_{4} \mathrm{Cl}$ did not depress the flotation of $\mathrm{NaCl}$ but showed an activation 
effect on $\mathrm{NaCl}$. The recovery of $\mathrm{NaCl}$ increased with an increase in the $\mathrm{NH}_{4} \mathrm{Cl}$ dosage and reached a maximum value of $97.55 \%$ at an $\mathrm{NH}_{4} \mathrm{Cl}$ dosage of $2000 \mathrm{~g} / \mathrm{t}$, indicating that $\mathrm{NH}_{4} \mathrm{Cl}$ promoted the flotation separation of $\mathrm{NaCl}$ and $\mathrm{KCl}$ with $\mathrm{DMP}$ as a collector.

\subsection{Adsorption Capacity Experiments}

Figure 4a presents the adsorption capacity of DMP on the $\mathrm{NaCl}$ and $\mathrm{KCl}$ surfaces. DMP adsorption was significantly higher onto the $\mathrm{NaCl}$ surface than on the $\mathrm{KCl}$ surface. The adsorption of DMP onto $\mathrm{KCl}$ and $\mathrm{NaCl}$ gradually increased and reached maximum values at dosages of 1300 and $1400 \mathrm{~g} / \mathrm{t}$, respectively. These values agree with the flotation experiment results. Figure $4 \mathrm{~b}$ illustrates that in the dosage range tested $\left(500-2500 \mathrm{~g} / \mathrm{t}\right.$ ), the adsorption capacity of $\mathrm{NH}_{4} \mathrm{Cl}$ onto the $\mathrm{KCl}$ surface was significantly higher than onto the $\mathrm{NaCl}$ surface. The adsorption amount of $\mathrm{NH}_{4} \mathrm{Cl}$ onto the $\mathrm{KCl}$ surface was about $50 \mu \mathrm{g} / \mathrm{g}$ higher than that on the $\mathrm{NaCl}$ surface and increased with an increase in the $\mathrm{NH}_{4} \mathrm{Cl}$ dosage. The difference between the adsorption amounts of the two minerals reached a maximum of $71.9 \mu \mathrm{g} / \mathrm{g}$ at the $\mathrm{NH}_{4} \mathrm{Cl}$ dosage $2500 \mathrm{~g} / \mathrm{t}$.
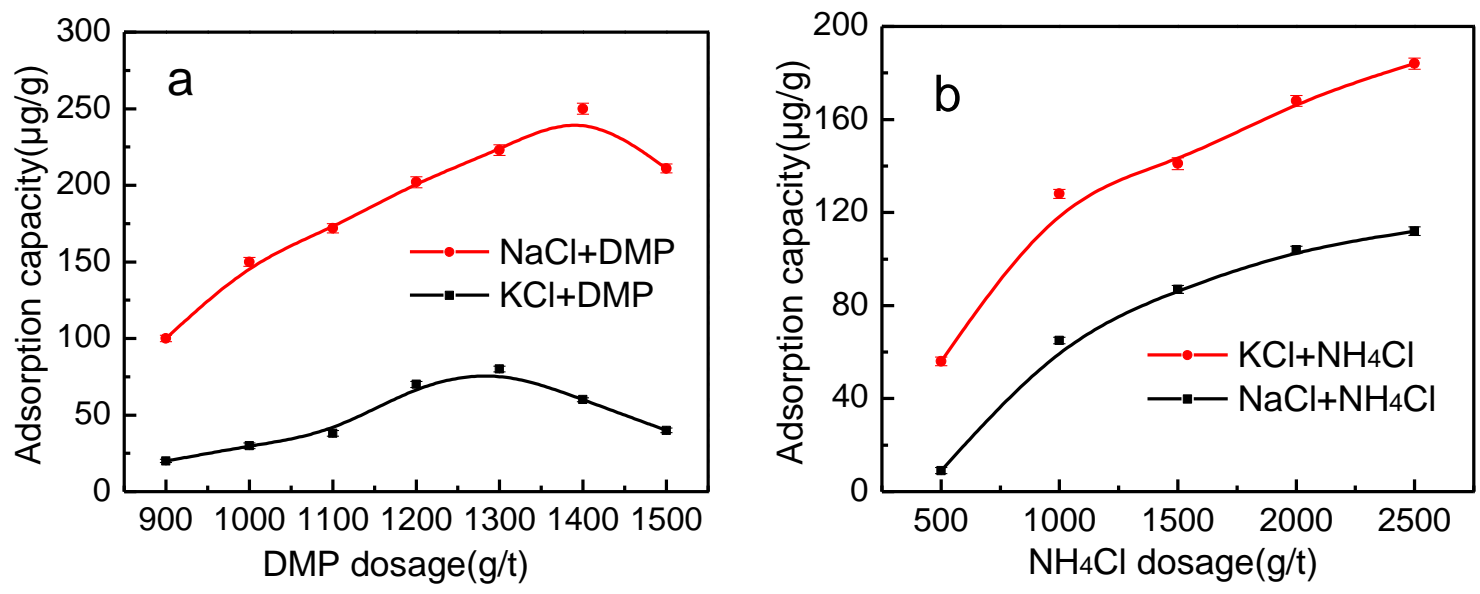

Figure 4. Absorption capacity of (a) DMP and (b) $\mathrm{NH}_{4} \mathrm{Cl}$ on the $\mathrm{KCl}$ and $\mathrm{NaCl}$ surfaces.

\subsection{FTIR Spectroscopy Analysis}

FTIR is commonly used to characterize the mechanism of the reaction between a mineral and a reagent. The FTIR spectra of $\mathrm{NH}_{4} \mathrm{Cl}, \mathrm{KCl}$, and $\mathrm{KCl}$ reacted with $\mathrm{NH}_{4} \mathrm{Cl}$ are presented in Figure 5. In the $\mathrm{NH}_{4} \mathrm{Cl}$ spectrum, the characteristic sharp band near $3137 \mathrm{~cm}^{-1}$ corresponds to the stretching $\mathrm{N}-\mathrm{H}$ vibration, while the band near $1402 \mathrm{~cm}^{-1}$ was assigned to the flexural vibration of the ammonium ion [20]. After the reaction between $\mathrm{KCl}$ and $\mathrm{NH}_{4} \mathrm{Cl}$ (Figure 5c), characteristic sharp bands near 1404 and $3137 \mathrm{~cm}^{-1}$ on the $\mathrm{KCl}$ surface, corresponding to the flexural vibration of the ammonium ion and the $\mathrm{N}-\mathrm{H}$ stretching vibration, respectively, were observed. After treatment with $\mathrm{NH}_{4} \mathrm{Cl}$ (Figure 5e), peaks from ammonium ion flexural and $\mathrm{N}-\mathrm{H}$ stretching vibrations were also observed, suggesting that $\mathrm{NH}_{4} \mathrm{Cl}$ adsorbed onto the $\mathrm{NaCl}$ surface. The spectra of $\mathrm{NH}_{4} \mathrm{Cl}$-treated $\mathrm{KCl}$ (Figure $5 \mathrm{c}$ ) and $\mathrm{NaCl}$ (Figure 5e) exhibited absorption peaks characteristic of $\mathrm{NH}_{4} \mathrm{Cl}$. However, no band shift was observed, indicating that the adsorption of $\mathrm{NH}_{4} \mathrm{Cl}$ on $\mathrm{KCl}$ and $\mathrm{NaCl}$ is dominated by physical adsorption. 


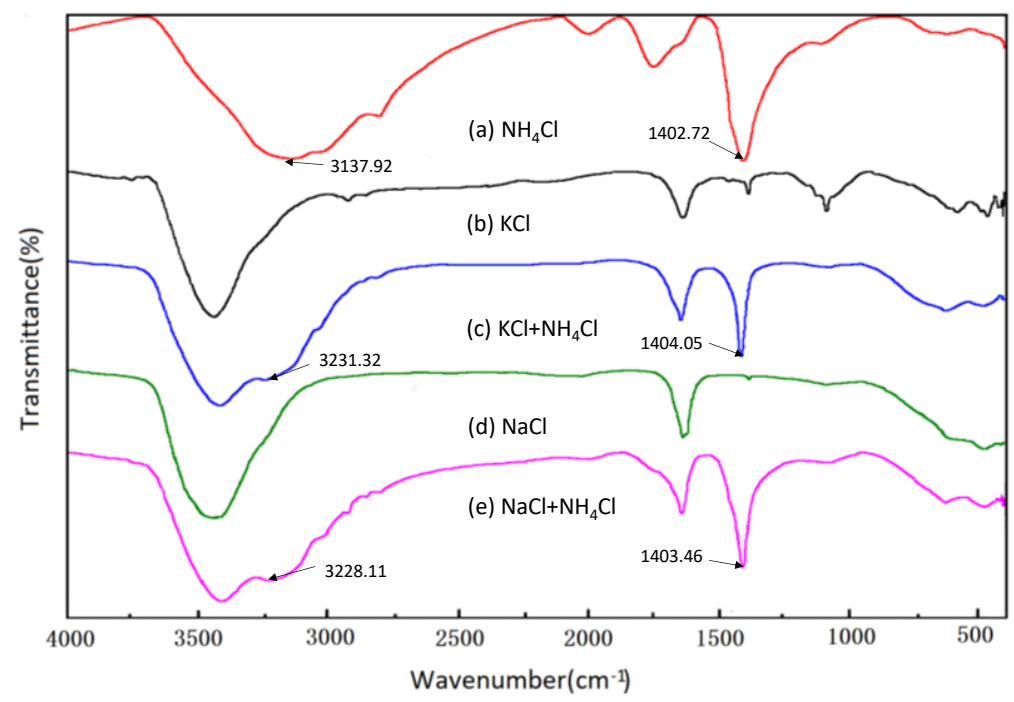

Figure 5. FTIR spectra of (a) $\mathrm{NH}_{4} \mathrm{Cl}$, (b) $\mathrm{KCl}$, (c) $\mathrm{KCl}+\mathrm{NH}_{4} \mathrm{Cl}$, (d) $\mathrm{NaCl}$, and (e) $\mathrm{NaCl}+\mathrm{NH}_{4} \mathrm{Cl}$.

The DMP FTIR spectra are presented in Figure 6a. The bands at 2922 and $2852 \mathrm{~cm}^{-1}$ were assigned to the $\mathrm{C}-\mathrm{H}$ stretching vibration $[21,22]$. Moreover, weak characteristic peaks of DMP at 3026 and $2802 \mathrm{~cm}^{-1}$ were detected on the $\mathrm{KCl}$ surface under the precondition that $\mathrm{NH}_{4} \mathrm{Cl}$ reacted with $\mathrm{KCl}$, suggesting that small amounts of DMP adsorbed onto the $\mathrm{KCl}$ surface. The characteristic peaks of DMP at 3029 and $2802 \mathrm{~cm}^{-1}$ were still significant in the $\mathrm{NaCl}+\mathrm{NH}_{4} \mathrm{Cl}$ spectrum (Figure 6e), indicating that DMP was effectively adsorbed onto the $\mathrm{NaCl}$ surface in the presence of $\mathrm{NH}_{4} \mathrm{Cl}$. Based on these results, it can be concluded that significantly strong physical adsorption of DMP occurs on the $\mathrm{NaCl}$ surface after treatment with $\mathrm{NH}_{4} \mathrm{Cl}$. On the other hand, DMP hardly adsorbs on the $\mathrm{NH}_{4} \mathrm{Cl}$-treated $\mathrm{KCl}$ surface. These FTIR results support the flotation results.

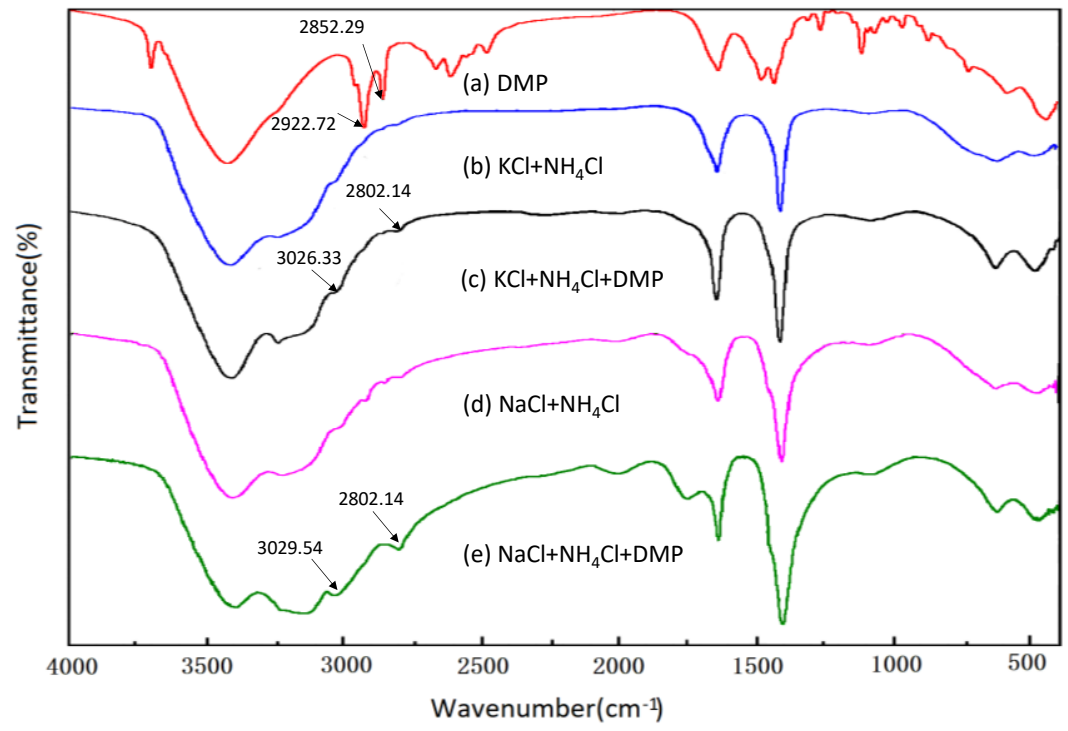

Figure 6. FTIR spectra of (a) DMP, (b) $\mathrm{KCl}+\mathrm{NH}_{4} \mathrm{Cl}$, (c) $\mathrm{KCl}+\mathrm{NH}_{4} \mathrm{Cl}+\mathrm{DMP}$, (d) $\mathrm{NaCl}+\mathrm{NH}_{4} \mathrm{Cl}$, and (e) $\mathrm{NaCl}+\mathrm{NH}_{4} \mathrm{Cl}+\mathrm{DMP}$.

\subsection{Computation Results by MD Simulations}

\subsection{1. $\mathrm{NH}_{4} \mathrm{Cl}$ Adsorption States on the $\mathrm{NaCl}$ and $\mathrm{KCl}$ Crystal Surfaces in Vacuum}

MD simulation was used to investigate the solid-liquid interface properties and determine the micro-adsorption structure on a molecular scale [23-26]. Studies have reported that $\mathrm{NH}_{4} \mathrm{Cl}$ adsorbs 
on $\mathrm{KCl}$ through the chloride ions, which act with the surface potassium atoms. Figure 7 presents the models of the mineral-reagent complex after $\mathrm{NH}_{4} \mathrm{Cl}$ adsorption in vacuum. Almost all the chloride ions absorbed onto the $\mathrm{KCl}$ surface and interacted strongly with the potassium atoms. Moreover, the ammonium ions were also close to the $\mathrm{KCl}$ surface, probably because of their interaction with the surface chloride ions and the chlorine atoms in the $\mathrm{KCl}$ crystal. On the other hand, in the $\mathrm{NaCl}$ system (Figure $\mathrm{7b}$ ), the ammonium and chloride ions were alienated from the surface and did not collect at the $\mathrm{NaCl}$ surface.
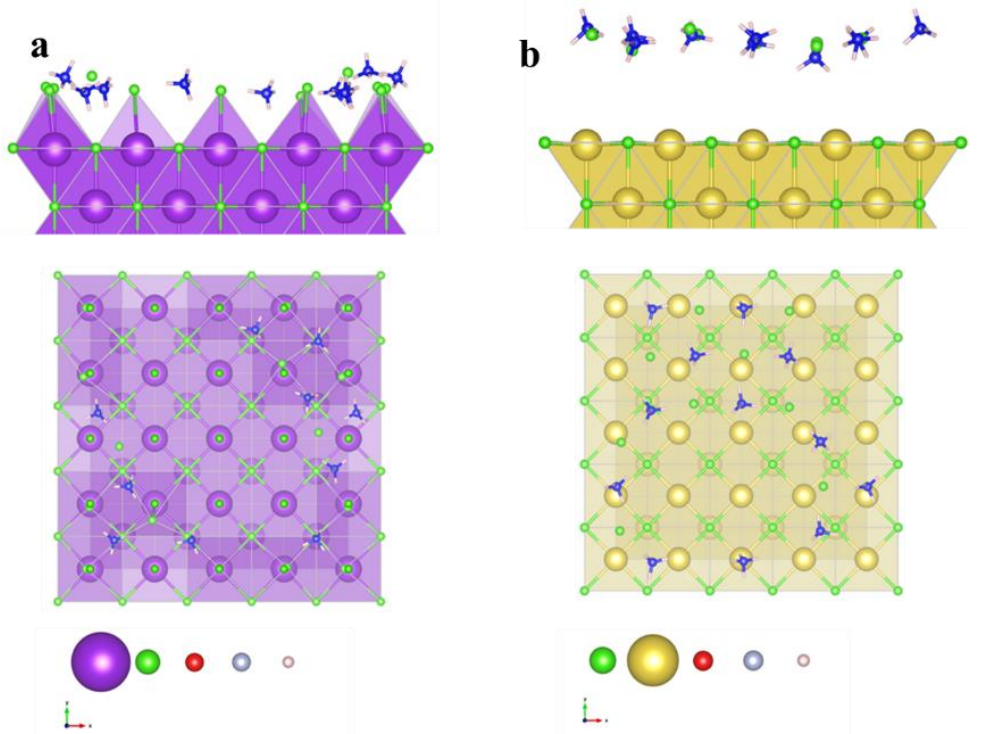

Figure 7. Front and top view snapshots of nine ammonium and chloride ions near the (a) $\mathrm{KCl}$ surface in vacuum and (b) $\mathrm{NaCl}$ surface in vacuum. The color scheme is as follows: red, oxygen atoms; white, hydrogen atoms; blue, nitrogen atoms; purple, potassium atoms; yellow, sodium atoms; and green, chlorine atoms.

3.4.2. $\mathrm{NH}_{4} \mathrm{Cl}$ Adsorption States on the $\mathrm{NaCl}$ and $\mathrm{KCl}$ Crystal Surfaces in the Presence of Water Molecules

Retaining the original vacuum condition, 200 water molecules were added to the system to investigate the effects of the ammonium and chloride ions on the $\mathrm{KCl}$ and $\mathrm{NaCl}$ surfaces in the presence of water as well as the hydrophilicity and hydrophobicity of the two minerals. Figure 8a illustrates that the ammonium and chloride ions interacted strongly with $\mathrm{KCl}$ and were effectively adsorbed onto the mineral surface. On the other hand, in the $\mathrm{KCl}$ system, the water molecules were close to the mineral surface because $\mathrm{KCl}$ is hydrophilic. The data in Figure $8 \mathrm{~b}$ revealed that in the presence of water molecules, the ammonium and chloride ions were further away from the $\mathrm{NaCl}$ surface because of the hydrophobicity of $\mathrm{NaCl}$. The above conditions were consistent with those observed under vacuum conditions and validated the conclusion reached on flotation. 
a

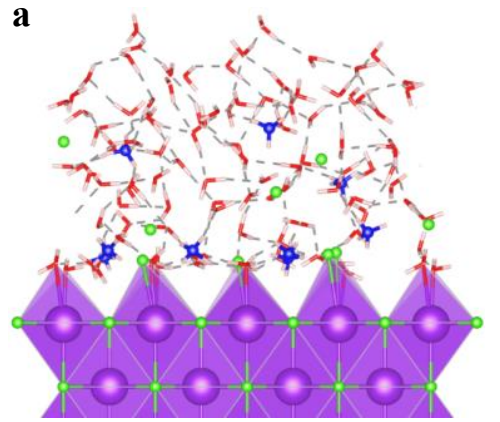

b
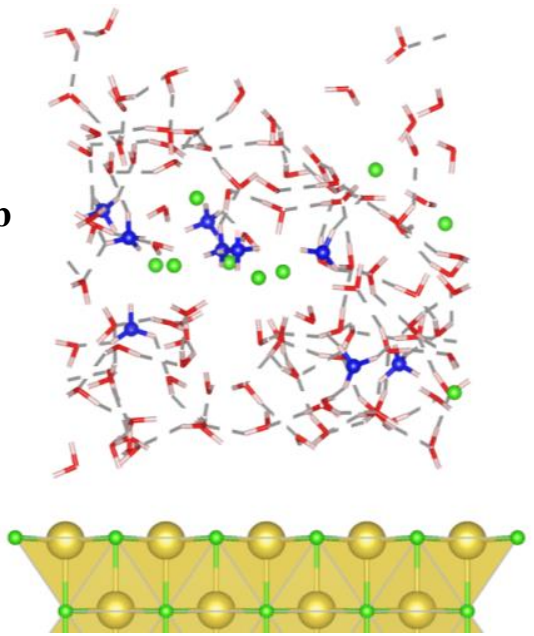

Figure 8. MD simulation snapshot of ammonium and chloride ions near the (a) $\mathrm{KCl}$ and (b) $\mathrm{NaCl}$ surfaces with 200 water molecules each. The color scheme is as follows: red, oxygen atoms; white, hydrogen atoms; blue, nitrogen atoms; purple, potassium atoms; yellow, sodium atoms; and green, chlorine atoms.

The analysis of the relative concentrations of the reagents as a function of distance from the

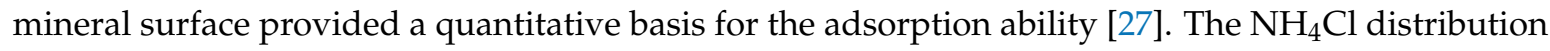
on different minerals could therefore be quantified by calculating the relative concentrations of the ammonium and chloride ions [28]. The concentration profiles along the $z$-axis were calculated with the normal $z$-axis on the mineral surface set as the zero point (Figure 9). After the interaction of $\mathrm{NH}_{4} \mathrm{Cl}$ with $\mathrm{KCl}$, the ammonium and chloride ions were both distributed at distances in the range 2-13 $\mathrm{A}$ from the $\mathrm{KCl}$ surface and 2-19 $\AA$ from the $\mathrm{NaCl}$ surface. The relative concentrations of the ammonium ions in the range 3-8 $\AA$ away from the $\mathrm{KCl}$ surface are all $>10 \%$, while the maximum relative concentration of ammonium ions $9.46 \AA$ away from the $\mathrm{NaCl}$ surface is $<10 \%$. Moreover, $>90 \%$ ammonium ions and

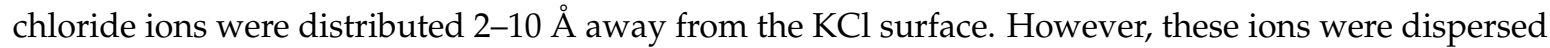
on the $\mathrm{NaCl}$ surface, indicating that $\mathrm{NH}_{4} \mathrm{Cl}$ exhibited a stronger intermolecular interaction with $\mathrm{KCl}$ than with $\mathrm{NaCl}$. The relative concentration distribution of the chloride ions on the $\mathrm{KCl}$ and $\mathrm{NaCl}$ surfaces was similar to that of the ammonium ions. In the aqueous solution system, analysis of the relative concentration results revealed that the ammonium and chloride ions were close to the $\mathrm{KCl}$ surface, indicating that the strong interaction between $\mathrm{NH}_{4} \mathrm{Cl}$ and $\mathrm{KCl}$ led to the strong adsorption of the former mineral onto the mineral surface. Conversely, the ammonium and chloride ions were far from the $\mathrm{NaCl}$ surface, indicating that $\mathrm{NH}_{4} \mathrm{Cl}$ exhibited a weaker intermolecular interaction with $\mathrm{NaCl}$ than with $\mathrm{KCl}$. The results of the MD simulations verified the flotation results.

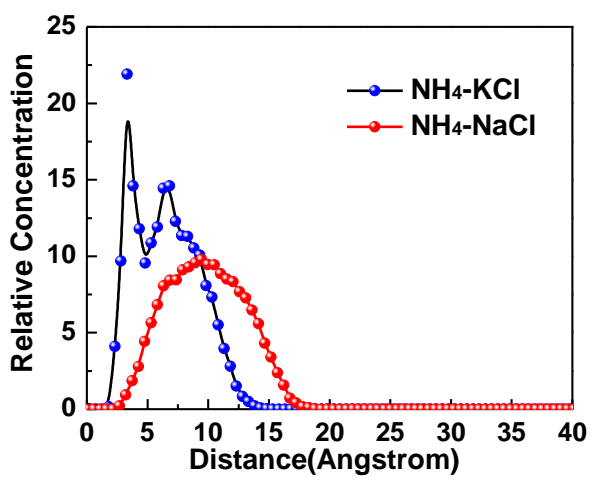

(a)

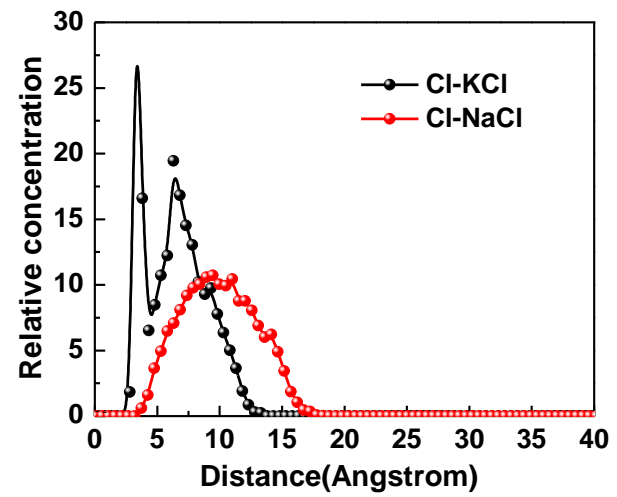

(b)

Figure 9. The $z$-direction relative concentration of the (a) ammonium ions and (b) chloride ions. 
The simulation results in this study were consistent with the surface charge theory [29], where the governing mechanism for soluble salt flotation comprised the electrostatic interaction between the salt surface and the collector species [30]. In the surface charge theory, $\mathrm{KCl}$ and $\mathrm{NaCl}$ carry opposite charges, $\mathrm{KCl}$ being negatively charged and $\mathrm{NaCl}$ being positively charged in their saturated brines. These speculations were later confirmed by the nonequilibrium electrophoretic mobility measurements [31]. Therefore, the flotation separation of $\mathrm{KCl}$ from $\mathrm{NaCl}$ was achieved because of the adsorption of cationic surfactants such as C12-C18 amine ions or positively charged collector colloids on the negatively charged $\mathrm{KCl}$ surface but not on the positively charged $\mathrm{NaCl}$ surface [31,32]. MD simulation results revealed that the adsorption of chloride ions onto the $\mathrm{KCl}$ surface resulted in a negatively charged $\mathrm{KCl}$ surface. The results verified the above theory that the $\mathrm{KCl}$ surface was negatively charged; thus, ammonium ions were adsorbed onto the negatively charged $\mathrm{KCl}$ surface by electrostatic attraction and alienated the positively charged $\mathrm{NaCl}$ surface because of electrostatic repulsion.

\section{Conclusions}

Dodecyl morpholine is a selective collector for the flotation of $\mathrm{NaCl}$ and $\mathrm{KCl}$. Reverse flotation is being applied in the industry and is more effective than traditional flotation, which employs long-chain ammonium compounds as collectors $[13,33]$. The addition of $\mathrm{NH}_{4} \mathrm{Cl}$ promoted the separation of $\mathrm{KCl}$ and $\mathrm{NaCl}$. The flotation tests revealed that $\mathrm{NH}_{4} \mathrm{Cl}$ exerts a considerable inhibitory effect on $\mathrm{KCl}$ so that the recovery was reduced to $<1 \%$. It also exhibited a significant activation effect on $\mathrm{NaCl}$ so that the maximum recovery value was $97.55 \%$.

The adsorption experiments and FTIR measurements indicated that DMP adsorption was significantly higher on the $\mathrm{NaCl}$ surface than on the $\mathrm{KCl}$ surface. However, the adsorption of $\mathrm{NH}_{4} \mathrm{Cl}$ onto the $\mathrm{KCl}$ surface was stronger than that on the $\mathrm{NaCl}$ surface and the difference increased with an increase in the $\mathrm{NH}_{4} \mathrm{Cl}$ dosage. The characteristic DMP peaks at $3029 \mathrm{~cm}^{-1}$ and $\sim 2802 \mathrm{~cm}^{-1}$ were still significant on the $\mathrm{NaCl}$ surface. On the other hand, the characteristic peaks detected on the $\mathrm{KCl}$ surface in the presence of $\mathrm{NH}_{4} \mathrm{Cl}$ were weak. Notably, $\mathrm{NH}_{4} \mathrm{Cl}$ and DMP were physically adsorbed onto the surfaces of both minerals.

MD simulations demonstrated that the adsorption of $\mathrm{NH}_{4} \mathrm{Cl}$ onto the $\mathrm{KCl}$ surface was very strong because of the presence of electrostatic forces. However, $\mathrm{NH}_{4} \mathrm{Cl}$ displayed weak interactions with $\mathrm{NaCl}$ and could not be adsorbed onto the $\mathrm{NaCl}$ surface. In an aqueous solution system, the $\mathrm{KCl}$ surface was hydrophilic, while the $\mathrm{NaCl}$ surface was hydrophobic. The relative concentration measurements indicated that the ammonium and chloride ions were close to the $\mathrm{KCl}$ surface but far away from that of $\mathrm{NaCl}$, indicating that $\mathrm{NH}_{4} \mathrm{Cl}$ exhibited stronger interactions with $\mathrm{KCl}$ than with $\mathrm{NaCl}$; this led to its stronger adsorption onto the $\mathrm{KCl}$ surface. The results in this study therefore confirmed that $\mathrm{NH}_{4} \mathrm{Cl}$ promotes the flotation separation of $\mathrm{NaCl}$ and $\mathrm{KCl}$ with $\mathrm{DMP}$ as the collector.

Author Contributions: Conceptualization, R.L. and L.W.; Methodology, L.W.; Software, M.T.; Validation, L.W., M.T.; Formal Analysis, H.L.; Investigation, R.L.; Resources, W.S.; Data Curation, H.L.; Writing-Original Draft Preparation, H.L.; Writing-Review \& Editing, R.L. and H.L.; Visualization, H.L.; Supervision, W.S.; Project Administration, R.L.; Funding Acquisition, W.S.

Funding: This study was financially supported by the Collaborative Innovation Center for Clean and Efficient Utilization of Strategic Metal Mineral Resources, the National 111 Project (No. B14034), and the Key Laboratory of Hunan Province for Clean and Efficient Utilization of Strategic Calcium-containing Mineral Resources (No. 2018TP1002).

Acknowledgments: We would like to thank the Central South University for providing us with the experimental platform.

Conflicts of Interest: The authors declare no conflict of interest. 


\section{References}

1. Li, E.; Du, Z.; Yuan, S.; Cheng, F. Low temperature molecular dynamic simulation of water structure at sylvite crystal surface in saturated solution. Miner. Eng. 2015, 83, 53-58. [CrossRef]

2. Larsson, S.; Gustafsson, G.; Häggblad, H.-^̊.; Jonsén, P. Experimental and numerical study of potassium chloride flow using smoothed particle hydrodynamics. Miner. Eng. 2018, 116, 88-100. [CrossRef]

3. Ozdemir, O.; Karakashev, S.I.; Nguyen, A.V.; Miller, J.D. Adsorption and surface tension analysis of concentrated alkali halide brine solutions. Miner. Eng. 2009, 22, 263-271. [CrossRef]

4. Cao, Q.; Du, H.; Miller, J.D.; Wang, X.; Cheng, F. Surface chemistry features in the flotation of KCl. Miner. Eng. 2010, 23, 365-373. [CrossRef]

5. Du, H.; Ozdemir, O.; Wang, X.; Cheng, F.; Celik, M.S.; Miller, J.D. Flotation chemistry of soluble salt minerals: From ion hydration to colloid adsorption. Miner. Metall. Process. 2014, 31, 1-20. [CrossRef]

6. Wachsmuth, U.; Brod, J. Process for the Selective Flotation of Kainite from Mineral Mixtures Using Sulfated Fatty Acids as the Collector Reagent. U.S. Patent 20170361335A1, 21 December 2017.

7. Berthon, R.; Mames, M.; Zimmerman, J.-P. Amine-amide collectors for the treatment of potash ores. U.S. Patent 3596763, 3 August 1971.

8. Titkov, S.; Sabirov, R.; Panteleeva, N. Investigations of alkylmorpholines-Collectors for a new halite flotation process. Miner. Eng. 2003, 16, 1161-1166. [CrossRef]

9. Monte, M.; Oliveira, J. Flotation of sylvite with dodecylamine and the effect of added long chain alcohols. Miner. Eng. 2004, 17, 425-430. [CrossRef]

10. Laskowski, J.; Castro, S. Flotation in concentrated electrolyte solutions. Int. J. Miner. Process. 2015, 144, 50-55. [CrossRef]

11. Perucca, C.F. Potash processing in Saskatchewan-A review of process technologies. CIM Bull. 2003, 96, 61-65.

12. Wu, Z.; Wang, X.; Liu, H.; Zhang, H.; Miller, J.D. Some physicochemical aspects of water-soluble mineral flotation. Adv. Colloid Interface Sci. 2016, 235, 190-200. [CrossRef]

13. Wang, X.; Miller, J.D.; Cheng, F.; Cheng, H. Potash flotation practice for carnallite resources in the Qinghai Province, PRC. Miner. Eng. 2014, 66-68, 33-39. [CrossRef]

14. Ozdemir, O.; Du, H.; Karakashev, S.I.; Nguyen, A.V.; Celik, M.S.; Miller, J.D. Understanding the role of ion interactions in soluble salt flotation with alkylammonium and alkylsulfate collectors. Adv. Colloid Interface Sci. 2011, 163, 1-22. [CrossRef] [PubMed]

15. Laskowski, J.S. From amine molecules adsorption to amine precipitate transport by bubbles: A potash ore flotation mechanism. Miner. Eng. 2013, 45, 170-179. [CrossRef]

16. Liu, X.; Xie, J.; Huang, G.; Li, C. Low-temperature performance of cationic collector undecyl propyl ether amine for ilmenite flotation. Miner. Eng. 2017, 114, 50-56. [CrossRef]

17. Yin, W.; Yang, B.; Fu, Y.; Chu, F.; Yao, J.; Cao, S.; Zhu, Z. Effect of calcium hypochlorite on flotation separation of covellite and pyrite. Powder Technol. 2019, 343, 578-585. [CrossRef]

18. Zhang, Y.; Hu, Y.; Sun, N.; Liu, R.; Wang, Z.; Wang, L.; Sun, W. Systematic review of feldspar beneficiation and its comprehensive application. Miner. Eng. 2018, 128, 141-152. [CrossRef]

19. Xu, L.; Tian, J.; Wu, H.; Fang, S.; Lu, Z.; Ma, C.; Sun, W.; Hu, Y. Anisotropic surface chemistry properties and adsorption behavior of silicate mineral crystals. Adv. Colloid Interface Sci. 2018, 256, 340-351. [CrossRef]

20. Maiti, K.S. Ultrafast N-H vibrational dynamics of hydrogen-bonded cyclic amide reveal by 2DIR spectroscopy. Chemical Physics 2018, 515, 509-512. [CrossRef]

21. Mal, N.K.; Kumar, P.; Fujiwara, M. Sorption properties and hydrothermal stability of MCM-41 prepared by pH adjustment and salt addition. In Studies in Surface Science and Catalysis; Sayari, A., Jaroniec, M., Eds.; Elsevier: Amsterdam, The Netherlands, 2002; Volume 141, pp. 445-452.

22. Liu, D.Y.; Sui, G.X.; Bhattacharyya, D. Properties and characterization of electrically conductive nanocellulose-based composite films. In Fillers and Reinforcements for Advanced Nanocomposites; Dong, Y., Umer, R., Lau, A.K.-T., Eds.; Woodhead Publishing: Sawston, UK, 2015; pp. 3-25.

23. Leermakers, F.A.M.; Koopal, L.K.; Goloub, T.P.; Vermeer, A.W.P.; Kijlstra, J. Confinement-Induced Symmetry Breaking of Interfacial Surfactant Layers. J. Phys. Chem. B 2006, 110, 8756-8763. [CrossRef]

24. Reimer, U.; Wahab, M.; Schiller, P.; Moegel, H.J. Monte Carlo study of surfactant adsorption on heterogeneous solid surfaces. Langmuir 2005, 21. [CrossRef] 
25. Tarek, M.; Bandyopadhyay, S.; Klein, M.L. Molecular dynamics studies of aqueous surfactants systems. J. Mol. Liq. 1998, 78, 1-6. [CrossRef]

26. Wang, L.; Sun, N.; Wang, Z.; Han, H.; Yang, Y.; Liu, R.; Hu, Y.; Tang, H.; Sun, W. Self-assembly of mixed dodecylamine-dodecanol molecules at the air/water interface based on large-scale molecular dynamics. J. Mol. Liq. 2019, 276, 867-874. [CrossRef]

27. Jang, C.; Lacy, T.E.; Gwaltney, S.R.; Toghiani, H.; Pittman, C.U. Interfacial shear strength of cured vinyl ester resin-graphite nanoplatelet from molecular dynamics simulations. Polymer 2013, 54, 3282-3289. [CrossRef]

28. Li, L.; Hao, H.; Yuan, Z.; Liu, J. Molecular dynamics simulation of siderite-hematite-quartz flotation with sodium oleate. Appl. Surf. Sci. 2017, 419, 557-563. [CrossRef]

29. Miller, J.D.; Yalamanchili, M.R. Fundamental aspects of soluble salt flotation. Miner. Eng. 1994, 7, 305-317. [CrossRef]

30. Roman, R.J.; Fuerstenau, M.C.; Seidel, D.C. Mechanisms of soluble salt flotation. I. Trans. Am. Inst. Min. Metall. Petrol. Eng. 1968, 241, 56-64.

31. Miller, J.D.; Yalamanchili, M.R.; Kellar, J.J. Surface charge of alkali halide particles as determined by laser-Doppler electrophoresis. Langmuir 1992, 8, 1464-1469. [CrossRef]

32. Yalamanchili, M.R.; Kellar, J.J.; Miller, J.D. Adsorption of collector colloids in the flotation of alkali halide particles. Int. J. Min. Process. 1993, 39, 137-153. [CrossRef]

33. Pan, B. Flotation of Halite and Sylvite from Carnallite with Dodecyl Morpholine; The University of Utah: Salt Lake City, UT, USA, 2013.

(C) 2019 by the authors. Licensee MDPI, Basel, Switzerland. This article is an open access article distributed under the terms and conditions of the Creative Commons Attribution (CC BY) license (http://creativecommons.org/licenses/by/4.0/). 